\title{
COVID-19 in Africa: a comparative analysis of early policy
}

\section{responses}

\section{David Olusegun Sotola 1 \\ Pregala Pillay 1 \\ Hafte Gebreselassie 1}

1 Stellenbosch University / School of Public Leadership, Stellenbosch - South Africa

The COVID-19 pandemic has caused turmoil around the world. In Africa, some similarities and differences could be observed in the nature of the outbreak and the policy responses across the continent. This article discusses the policy responses and reflects on their effectiveness as a containment strategy. We speculate on why these strategies seem to work or not, and the lessons therein. The analysis also examines the setting up of crisis teams and whether they indicate lack of trust in the existing public administration system. The article argues that though South African cases and testing diverged significantly from the rest of the continent, a wider similarity can be observed in pandemic management across the continent. The article identifies some factors including quick and early measures, recent experience managing epidemic/health crises, and a display of some form of community resilience acquired over years of living in a state of poor governance as some of the important factors in the management of the pandemic. We find there is a dearth of scholarship on crisis management in the context of public administration and suggest this should be an object of future study in the field. The use of ad-hoc crisis teams that assume emergency powers is a common practice, but there is insufficient rigorous analysis to show their effectiveness and impact on existing bureaucratic institutions.

Keywords: COVID-19; Africa; policy response to the pandemic; crisis management in the public sector; lockdown approach.

\section{COVID-19 na África: uma análise comparativa das primeiras políticas de resposta}

A pandemia da COVID-19 causou grande turbulência em todo o mundo. Entre os países africanos pode-se perceber semelhanças e diferenças tanto em relação a natureza do surto como nas respostas políticas implementadas. Esse artigo discute essas respostas e reflete sobre sua eficácia como estratégia de contenção da pandemia. Especulamos as razões pelas quais essas estratégias parecem funcionar (ou não) e quais são as lições aprendidas, bem como examinamos a criação de 'equipes de crise' e se essas equipes demonstram confiança no sistema de administração pública existente. A análise nos permite argumentar que, embora a manifestação dos casos e os testes conduzidos na África do Sul tenham divergido significativamente do observado no resto do continente, há uma semelhança em geral em relação a gestão da pandemia em toda a África. Identificamos alguns elementos que refletem essa similaridade na gestão, entre eles a adoção de medidas rápidas e precoces, a experiência recente no gerenciamento de epidemias/crises de saúde e a existência de alguma forma de resiliência da comunidade, adquirida ao longo de anos de experiência em lidar com um estado de falta de governança. Ainda, observamos a escassez de estudos sobre gestão de crises no contexto da administração pública e sugerimos futuros trabalhos na área. Finalmente, percebemos que o uso de 'equipes de crise' constituídas especificamente e com poderes para lidar com a situação de emergência é uma prática comum. Entretanto, não há uma análise rigorosa suficiente para mostrar que essa estratégia é eficaz e tem impacto nas instituições burocráticas existentes.

Palavras-chave: COVID-19; África; resposta política à pandemia; gestão de crises no setor público; abordagem de confinamento. 


\section{COVID-19 en África: un análisis comparativo de las políticas de primera respuesta}

La pandemia de COVID-19 causó una gran conmoción en todo el mundo. Entre los países africanos, se pueden observar similitudes y diferencias tanto en relación con la naturaleza del brote como en las respuestas políticas implementadas. Este artículo analiza esas respuestas y reflexiona sobre su eficacia como estrategia de contención de una pandemia. Especulamos sobre las razones por las que estas estrategias parecen funcionar (o no) y cuáles son las lecciones aprendidas, además de examinar la creación de "equipos de crisis" y si estos equipos muestran confianza en el sistema de administración pública existente. El análisis nos permite argumentar que, aunque la manifestación de casos y pruebas realizadas en Sudáfrica ha divergido significativamente de la observada en el resto del continente, existe una similitud en general en relación con el manejo de la pandemia en África. Identificamos algunos elementos que reflejan esta similitud en la gestión, incluida la adopción de medidas rápidas y tempranas, la experiencia reciente en el manejo de epidemias/crisis de salud y la existencia de alguna forma de resiliencia comunitaria, adquirida durante años de experiencia en lidiar con un estado de falta de gobernanza. Además, notamos la escasez de estudios sobre gestión de crisis en el contexto de la administración pública y sugerimos trabajos futuros en el área. Finalmente, percibimos que el uso de "equipos de crisis" específicamente constituidos y capacitados para hacer frente a la emergencia es una práctica común. Sin embargo, no existe un análisis suficientemente riguroso para demostrar que esta estrategia es efectiva y tiene un impacto en las instituciones burocráticas existentes. Palabras clave: COVID-19; África; respuesta política a la pandemia; gestión de crisis en el sector público; enfoque de contención.

\section{INTRODUCTION}

The COVID-19 pandemic has created turmoil around the world. Though it is epidemiological, but it impacts transcends the health sector with several countries enforcing lockdowns and government assuming emergency powers. From the data on the spread, the mortality rate and intensity of spread vary across countries, but the containment policy measures have been similar.

In Africa, some similarity and differences could be observed in the nature of the outbreak and the policy response across the continent. This article draws out these policy responses and reflects on their effectiveness as a containment strategy. We speculate on whether these strategies seem to work and why and what lessons therein. The analysis also examines the degree of emergency power and whether they show trust or lack of trust in the existing public administration system.

This article is desk-based with data drawn from several online sources as referenced in relevant places. The analysis was presented in form of basic statistical analysis and tabular summary of policy responses. The consequent discussion was a reflection on the summary statistics and real-time observation of African countries pandemic contexts. This methodological approach derived from the evolving nature of the pandemic. Though South African diverged significantly in terms of cases and testing, a wider similarity can be observed in pandemic management across the continent. The article cites examples that cut across the various sub-regions (Eastern, Northern, Western and Southern Africa) and also takes considerations of the observable dynamics of the virus across the continent.

This article contributes to emerging knowledge for management of pandemic and social crisis generally using the example of COVID-19 pandemic. More specifically, it should be considered as a lay-out of hypothetical insights upon which future research could be based. COVID-19 is a sudden and unexpected crisis, a fact-based reflection of this nature on the containment policies could help in documenting global, continental and local actions and variations, thereby show lessons on how to address similar occurrence in the future. Readers should take note that it is still an evolving pandemic and the discussions presented here are informed by the state of the virus as at early October 2020. 
The article is segmented into four. Following the introductory section above is section two which presents background facts on COVID-19 in Africa with statistics on cases, death and testing across many countries. The third section discusses the policy measures comparatively. The last section presents the concluding reflections.

\section{COVID-19 IN AFRICA}

The corona virus infection first emerged in the continent in February 2020. The index case on the continent was recorded in Egypt on February 142020 (Al-Jazeera, 2020). The first case for sub-Saharan Africa was in Nigeria on $27^{\text {th }}$ February 2020 (Adepoju, 2020). Both cases, like most of the early cases, were European travelers into the continent(Adepoju, 2020; Al-Jazeera, 2020). Between March and May, 2020, the trajectory of the spread, hospitalization and death across Africa was minimally dispersed with confirmed cases ranging between one in Lesotho and 16443 in South Africa, and death also from zero in many countries to 665 in Egypt (Worldometers Coronavirus, 2020). By June and July however, there was a sharp divergence in cases with nine countries accounting for over 80 per cent of all cases (see Figure 1). South Africa alone accounts for up to 40 per cent of the cases in Africa. From inception to October 2020, most countries in the continent have recorded small and minimal cases. In some countries, like Comoro and Lesotho, they recorded only one case each at as early May and less than 2000 cumulative cases by October 2020.

FIGURE 1 SPREAD OF CASES ACROSS AFRICAN COUNTRIES OCTOBER 2020

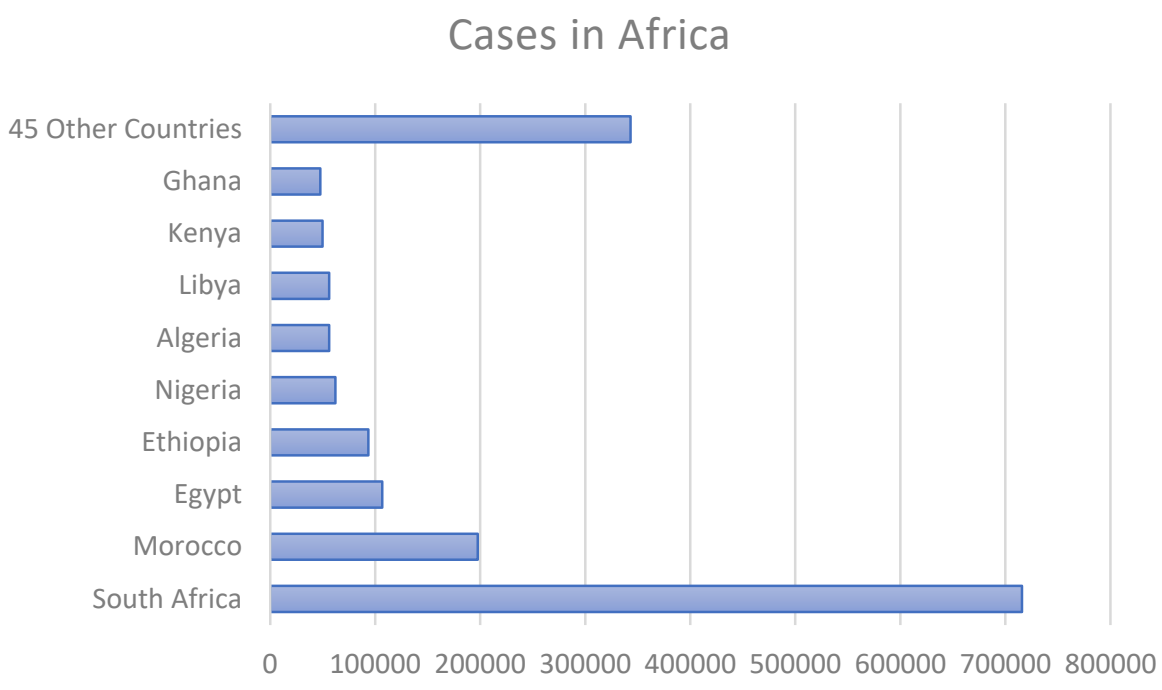

Source: John Hopskins University (2020).

There are also regional disparities within the continent. Figure 2 presents the spread of cases and death across the sub-regions within the continent. The chart shows the disparities across the sub-region, and when considered alongside Figure 1, they further confirmed argument around the domination of some regions on the manifestation of the pandemic. 


\section{Regional Distribution of Cases and Death}

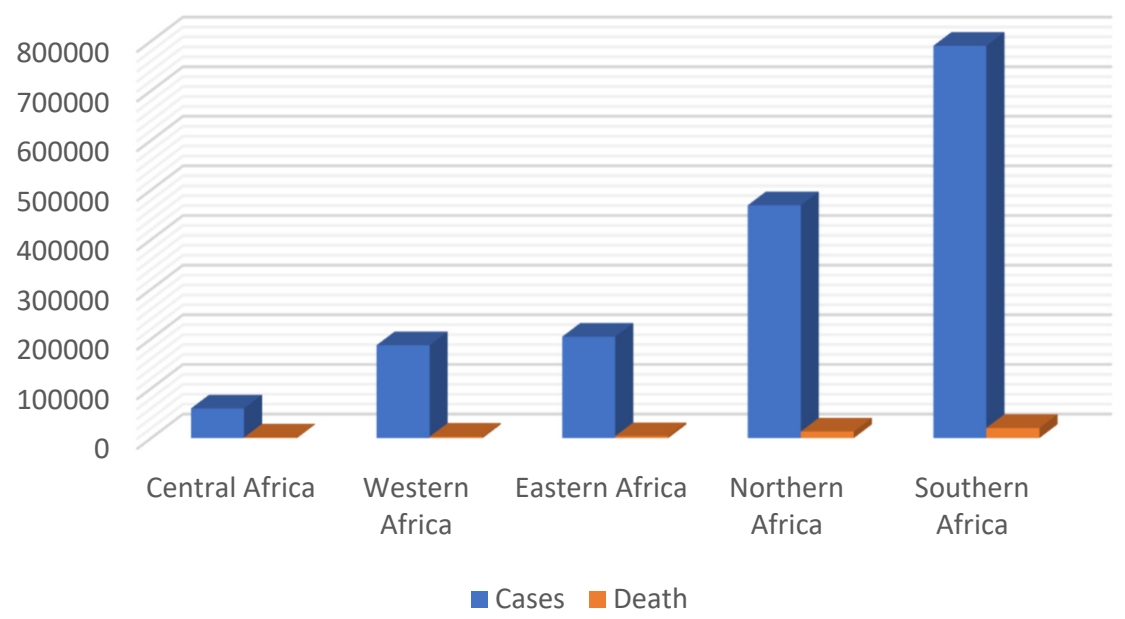

Source: African Centre for Disease Control (ACDC).

This pattern is dissimilar to Europe and United States of America (USA) where number of confirmed cases increased sharply from just a few to thousands in 8 weeks (from March to May 2020), and they have a significant share of the global cases and as at November 2020 was experiencing a second wave of lockdowns due to the continuous spread of the virus.

\section{FIGURE 3 GLOBAL COMPARISON OF CASES, DEATH, ACTIVE-CASE OCTOBER 2020}

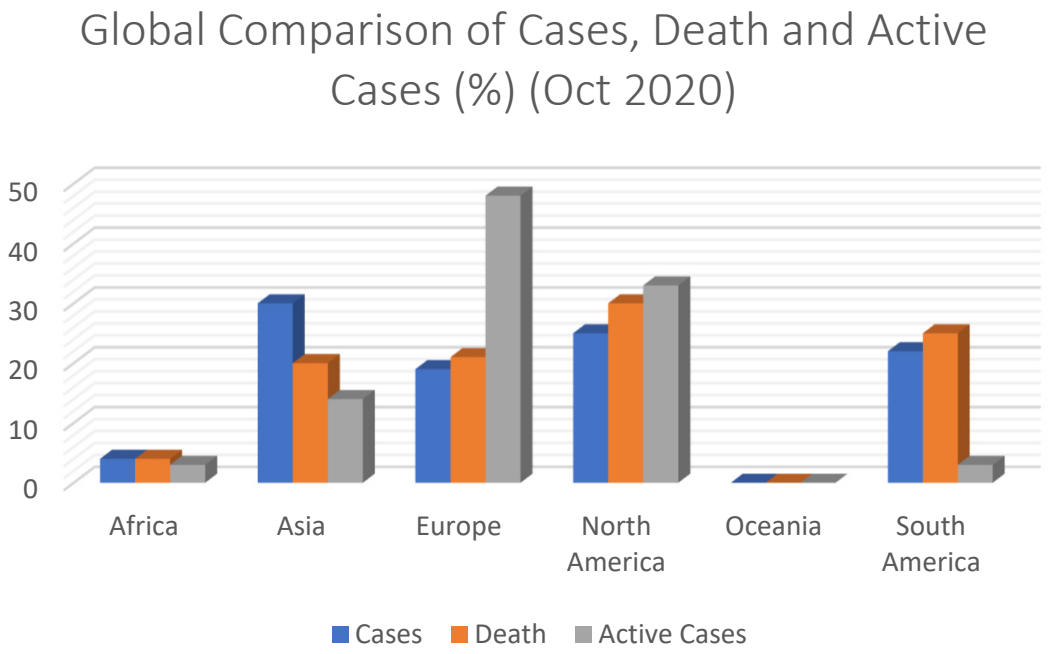

Note: The chart above is presented as a share of cases in percentage approximated to the nearest whole number. Active case means number of infected that is not cured yet.

Source: Worldometers Coronavirus Tracker (2020). 
As at the time of writing (October 2020), Africa has about 4 per cent of global cases and 4 per cent of death (See Figure 4). This has fluctuated between 1 and 5 per cent since April to October 2020. Africa share of cases and death was $1 \%$ and $0.73 \%$ respectively in May 2020. It is still an evolving pandemic and it is not obvious whether Africa has reached the peak of cases. Apart from South Africa with a sharp and sudden jump in cases, other countries in the continent have not seen the type of massive rise in confirmed cases as seen Europe and North America and there are speculations as to the reasons. There are concerns that the current number of confirmed cases is just a reflection of testing capacity and a poor indication of actual spread, especially as analysis shows that cases and testing correlate strongly. Some preliminary studies have reported that number of cases has linear relationship with the testing (Our World in Data, 2020).

This understanding that low testing may be responsible for the lower cases is being used to support the advocacy on the need to increase testing as a way to determine the spread. But it seems the low testing is also an indication of low testing capacity and a reflection of the state of the healthcare infrastructure generally (see Figure 4). The testing rate may also have to do with the testing criteria and methods. In many countries, there are specific criteria that are set to qualified for testing including medical symptoms, contact with established case and recent travel history (National Institute for Communicable Disease (NICD), 2020). Some countries like Ghana are also using Pool Testing which pooled sample (Alamisi, 2020) which increased the testing rate and number. The rate of testing may also be related to health insurance coverage, as data from South Africa shows that about $60 \%$ of test were conducted by private sector health services (Department of Health, 2020) and with medical insurance coverage. It may be important that any evaluation of rate of testing as a variable of interest should consider these nuances.

\section{FIGURE 4 STATISTIC OF HEALTHCARE INFRASTRUCTURE OCT 2020}

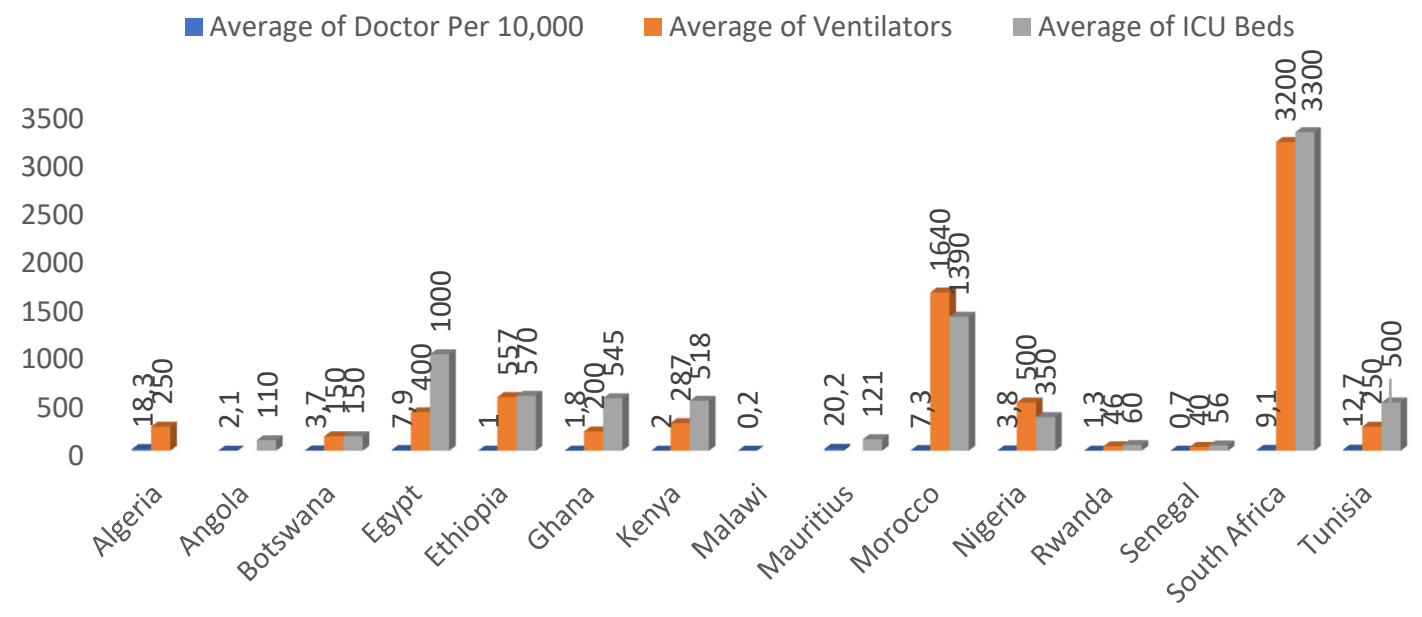

Note: Data on ventilator is not available for (Angola, Malawi, Mauritius); Data on number of ICU beds not available (Algeria, Malawi). Source: Reuters (2020b). 
Many African countries have increased their testing capacities since February, but testing is still low generally. But there are other indicators that could also proxy spread. These may include a sudden, and sharp increase in hospitalization and death for flu-like cases in the last three months. It will be difficult to hide mass infection or death for long. If it is the case that unreported cases are self-medicating, there should be a corresponding increase in OTC (over-the-counter) purchase of some drugs. It could also mean that undetected cases are getting cured, and this mean that selfmanagement is under-explored as a treatment strategy.

In any case, the low number of cases compared to Europe and the USA is fueling speculations on why there are low cases in most African countries (Sotola, 2020). Some speculative reasons that support this include quick action before it gains a foothold, the youthful population, the lower smoking prevalence compares to Europe and USA, experience managing epidemics like Ebola, Lassa fever among others. These are probably speculative and premature as they need further study, but similar reasons have been cited as reasons for the low cases in South Asia (Agrawal, 2020).

Local innovations are being implemented to increase testing and curtail community transmission. Africa countries are undertaking community screening and contact tracing (Africa Centre for Disease Control, 2020). South Africa and Nigeria are engaging ad-hoc workers to visit households in townships and communities. They are to conduct preliminary checks and send those perceived as potential cases for test (David \& Mash, 2020). This may prove to be a useful strategy in checking community transmission. This is based on thinking that a high number of the infected are asymptomatic, may therefore not seek medical treatment and go unreported. Also, rural and community dwellers showing symptoms may not seek orthodox care as they may perceived the symptoms differently and result to herbal or local treatment which could worsen community spread. Additionally, some regions are establishing drive by sample collection Centres where testing samples are to be collected.

\section{COVID-19, POLICY RESPONSE AND PUBLIC ADMINISTRATION}

The policy responses have been similar across Africa. Almost all countries have implemented measures for social/physical distancing, mass or symptomatic testing, compulsory quarantine or isolation for suspected or confirmed cases, partial or full suspension of international travels and economic palliative measures. 
COMPARISON OF CONTAINMENT STRATEGY IN SELECTED AFRICAN COUNTRIES

\begin{tabular}{|c|c|c|c|c|}
\hline Country & $\begin{array}{l}\text { Social/Physical } \\
\text { distancing }\end{array}$ & Testing Approach & Nature of Lockdown ${ }^{1}$ & $\begin{array}{c}\text { Ban International } \\
\text { travel }\end{array}$ \\
\hline Algeria & Yes & $\mathrm{Na}$ & National Lockdown & yes \\
\hline Angola & Yes & $\begin{array}{l}\text { Symptomatic testing and } \\
\text { contact tracing of confirmed } \\
\text { cases }\end{array}$ & National Lockdown & yes \\
\hline Bostwana & Yes & $\mathrm{Na}$ & National lockdown & yes \\
\hline Cameroun & Yes & $\mathrm{Na}$ & National Lockdown & yes \\
\hline $\begin{array}{l}\text { Democractic } \\
\text { Republic of Congo }\end{array}$ & Yes & $\mathrm{Na}$ & National Lockdown & Yes \\
\hline Egypt & Yes & $\mathrm{Na}$ & National lockdown & Yes \\
\hline Ethiopia & Yes & Symptomatic & No Lockdown & No \\
\hline Ghana & Yes & Pooled testing & National Lockdown & yes \\
\hline Kenya & Yes & $\begin{array}{l}\text { Symptomatic testing and } \\
\text { contact tracing of confirmed } \\
\text { cases }\end{array}$ & National Lockdown & yes \\
\hline Morocco & Yes & & National Lockdown & yes \\
\hline Nigeria & Yes & $\begin{array}{l}\text { Symptomatic testing and } \\
\text { contact tracing of confirmed } \\
\text { cases }\end{array}$ & Lockdown in selected states & Yes \\
\hline Rwanda & Yes & & National Lockdown & yes \\
\hline Senegal & Yes & \multicolumn{2}{|c|}{ Symptomatic testing and contact tracing of confirmed cases } & yes \\
\hline South Africa & Yes & Symptomatic testing and & National Lockdown & yes \\
\hline Tanzania & Yes & na & National lockdown & yes (late) April 14 \\
\hline Uganda & Yes & na & National Lockdown & yes \\
\hline
\end{tabular}

Source: Elaborated by the authors. ${ }^{1}$

The similarities in policy response could be linked to the transboundary nature of the pandemic and the fact that policy precedents exist from Asia countries where the virus originated. China, Hongkong, Singapore etc. have implemented most of these measures.

As shown in Box 1, the nature of lockdown varies from country to country. While some implemented a national lockdown (South Africa, Rwanda) some implemented a regional lockdown based on where the virus seems to be rampaging (Nigeria, Ethiopia). This type of policy implementation

${ }^{1}$ Lockdown specifically refers to state-imposed restriction on movement and daily human activities including business, social, education, travels etc. due to the COVID-19 pandemic. It came into wider usage during this pandemic across the world. 
has implication on inter-governmental relations especially on the relationship between the national and sub-national units. The dynamics seem different for each country, but some of the common facts could help situate an agenda for future research. For instance, some of the necessary resources to enforce a lockdown are nationally controlled e.g. police and military forces, etc. Are there differences in lockdown outcome across the regions? what best account for them?

In many countries, some sort of 'crisis team', with emergency powers, were set-up. The nomenclatures are different across countries but they are imbued with emergencies powers. It is called Presidential Task force on Coronavirus Control, National Command Council, and National Public Health Emergency Operation Center in Nigeria, South Africa and Ethiopia respectively. These crisis management bodies show that there is a belief that the crisis is beyond the administrative/management capacity of the existing public administration. This may suggest lack of trust in the capacity of the existing management system. Trust in the capacity of the existing public administration has been cited as one of the reasons why there was no special anti-COVID-19 measure in Sweden (Karlson, Stern \& Klein, 2020). Extant literature have shown that countries with high level trust in existing public administration system addresses social problem or disaster, e.g. anticorruption, through the existing system, as they believe the existing legal institution is capable of addressing the challenges (Gemperle, 2018).

Some countries have taken extreme contrarian posture. Cameroun President has not given any address to the nation, Tanzania and Burundi Presidents made statements that suggest they are unconvinced on the corona virus science (Adeoye, Allison, Atabong \& Brima, 2020; Kell, 2020). The WHO has listed these countries among those to be worried about.

As the time of writing (October 2020), the virus is still a serious public health crisis, but economic reality is forcing many countries to ease the lockdown mostly in phases. South Africa created an 5 -stage alert system with first stage being a near normality allowing economic and modulated human activities and five being a reversion to the full lockdown (Department of Health, 2020). The National Command Council will decide what stage of lockdown to be implemented based on their review of the virus spread and fatality (Department of Health Republic of South Africa, 2020).

Nigeria has issued similar ease of lockdown order for essential and economic activities (Office of the Secretary to the Government of the Federation Nigeria, 2020). Many other countries including, Ghana, Ethiopia, Algeria, Morocco, Uganda, and so on, have eased the lockdown using various approaches. In the South Africa's 5-stage alert system, the first stage represents a near normality and the fifth stage is a full lockdown. This may make the process less arbitrary and how the lockdown will proceed could be predicted.

Some quick increase in health system capacity can also be observed. In Nigeria, for instance, the Laboratory with molecular testing capacity increased from under 10 to 25 from April to May (Sotola, 2020). There were similar impacts on key health infrastructure in other countries. 


\section{CONCLUDING REFLECTIONS}

The state of the pandemic in Africa presents a mixed result. Though there have been high number of cases in few countries, but the overall picture still suggests that a case exist that the policy responses implemented across the continent seem to have some effect in curtailing the spread. There has been late spike in cases in Africa from 1 per cent share of global cases in May to about 5 percent in August 2020, and 4 per cent in October, but as shown previously, the spike in cases is driven by few countries and these countries shared about 80 per cent of the cases and death.

South Africa alone, has about 50 per cent of the cases as at July, but has reduced to about 40 per cent in October. South Africa case doesn't compare with the rest of the continent and it is a clear outlier. Some commentators have argued that its case is best compare with South America than with Africa (Friedman, 2020). This is not peculiar to COVID-19 as Friedman (2020) argued that it is both an highlight of the deep historical inequalities and a reflection of leadership style that always aim to mirror the first world (Friedman, 2020).

To date in Africa, there is no indication that the hospitalization and death has overwhelmed the health system in the way similar to Europe, USA or China where their health system seems to have been initially overwhelmed (Horowitz, 2020). This is quite contrary to other epidemic like HIV/AIDS, Ebola, many of which turned to be a predominant African epidemic or even originated from there. Moreover, hospitalization rate has been low in Africa. Using South Africa data, less than 20 per cent of those infected are hospitalized and less than 5 per cent requires high-care, ICU, vent and oxygen (Department of Health, 2020).

Reflectively, some lessons can be gleaned from the early measures. First is that the speed of response matters. It seems the early, quick and decisive response could be an important containment measure. Almost all Africa countries have strong measures in place when there were still no case or few cases. Countries like Niger, Uganda, Lesotho already instituted preventive measures when they had no case (Worldaware, 2020). This is quite different from the Europe and USA where the virus was only been taken seriously after it has spread steeply. A clear lesson is that early response matters in public health crisis.

A second point is that previous experience managing health and governance crises seems to be helpful. Many parts of the continent have experienced or still experiencing epidemic and the management system implemented for those were very helpful for COVID-19. There was Ebola in West and Central Africa, Tuberculosis in South Africa, Aid/HIV, Cholera, Polio in many other parts. A local Centre for Disease Control (CDC) primed for response exist in many countries and many were established more recently to manage an ongoing epidemic. South Africa deployed some of its capacity on Tuberculosis management. Previous experience managing these crises seems helpful in designing or localizing the containment measures and on public engagement. Thinking counterfactually, there could have been low governance response and lots of trial and error policies which would have resulted in massive death and cases.

A third point is policy communication and transparency. The effectiveness of emergency measures seems to rely a lot on social trust and perception of good leadership. In some countries like Ghana, South-Africa, Rwanda, the citizen support for the measures can be observed through various positive comments on social media. There were constant communication activities; Presidential media chat/ 
briefing, meeting and stakeholder engagement including visiting to contact-tracing call Centres by the national leaders like Vice-President. This point was similarly reported in Singapore where political and policy communication/messaging was said to be clear, consistent and well informed (Quah, 2020). One basic logic why this is turning out to be important is that the involvement of President of country means the issue is being prioritised, and that the country's topmost leadership is fully aware of the issues and the necessary resources are being deployed.

Some of the outcome of the containment policy may be linked to the robustness of the existing health infrastructure. The data seems to strongly suggest that management of the spread and cases reflects the overall state of the healthcare infrastructure and will regress the to the governance capacity. The testing capacity, number of hospital beds, existing health system/institutions are important contributory factors. The signs are emerging towards this. John Nkengasong, the Head of Africa Centre for Disease Control recently called global attention to the continent's limited testing capacity especially on diagnostic tools and reagents (Nkengasong, 2020).

COVID-19 may lead to change in the perception of direction of the global order as countries may look inward than outward. This will have implications on public governance philosophy and public administration. Countries may now want to build internal capacity in a way to forestall possible future disruptions. There are reports of collapse of global supply chain especially those with reliance on China/Asia (Govindarajanm \& Bagla, 2020). It is not obvious whether this perception will endure. Rather, COVID-19 is showing vulnerability that are inherent in an interconnected world. While this may be interpreted to mean the need to slow down the current globalization wave, but a counterintuitive understanding of it is that the world needs to build global anti-pandemic capacity together. In recognition of its vulnerability and gaps in its public health system, there has been demonstration of efforts in building the Continent's collective response through the African Centre for Disease Control based at the African Union (Nkengasong, 2020; Signé \& Treacy, 2020).

Across the continent, there is a wider use of an approach of setting up ad-hoc bodies to managed the crisis. This in a way suggest lack of trust in the existing bureaucratic capacity. This is in line with the pattern in literature that developing countries tend to set-up more specific/single purpose bureaucratic institutions as against the developed countries which tend to have more trust in existing institutions (Gemperle, 2018).

The above point makes it necessary to raise an observation on the lack of research focus on crisis and crisis management within the discipline. A search on several database shows there is a dearth of publications, which suggests there is not enough study on crisis and public administration being done either within the discipline or from cognate fields. This should be prioritised as an object of future studies as COVID-19 seems to shows the need for a body of knowledge documenting and showing direction on how public administration should be done in public crises and emergency situation. Governments are defaulting to setting-up ad-hoc government unit for crisis management but Sweden did no such thing as she relies on existing administrative system (Karlson, Stern \& Klein, 2020), an in-depth study could show some insights on best approach and in what context.

The policy measures implemented also shows that curtailing epidemic is not strictly a healthcare issue. While the virus is a healthcare problem, the possible ramifications cut across economy, education, businesses etc. The policy measures and conversations show there an understanding of these wider 
implications. However, policy measures adopted mirror the global approach and may need to be better contextualized in future. For instance, the lockdown in many of the countries are being relaxed. This is based on the reality of emerging unintended consequences of job/income loss, economic collapse and increased criminal activities (Sotola, 2020). A large part of African economies is informal and relies on daily activities and income. There is therefore a sustainability question on lockdown as a containment strategy. There are fears around second wave of the virus, it is not however clearly feasible that complete lockdown as implemented previously will be a feasible idea.

Various assessment seems to show that lockdown has worked as a frontal containment measure, and as Zweli Mkhize the South Africa Minister of Health said lockdown has reached the limit of its effectiveness in delaying the COVID-19 infection peak, on our calculations, a further lockdown was not going to be of any benefit' (Child, 2020). But, if the virus fester for long, the state capacity including the administrative, fiscal and governance capacities will be pushed to the limit. It is not completely obvious whether Africa countries have used the lockdown to buy-time and increase their preparedness for instance to build capacity for testing. It may be that African countries just followed the lockdown wave and may have failed to achieve optimal outcome from it.

There is a dangerous dimension of conspiracy theories around the virus influencing perception in the region. This is worsened by the fact that many with the infections are asymptomatic and there is less hospitalization than initially thought. This is partly why some force were being used in enforcing the lockdown in some countries.

It is early days, but African countries seem to have done relatively well given their development status. This is true especially in comparison to Europe and US, where the virus appears to have overrun their healthcare capacity and Cuban and Chinese health professionals were invited to some European countries (Reuters, 2020a); and the USA actually changed its immigration policy to allow more medical practitioners from oversea a faster immigration progress (State Department @TravelGov, 2020).

The virus seems to be following a different trajectory in Africa. While the virus spread was peaking in Europe and the USA in May and June, it was just emerging in the Africa and many of the countries are just ramping up testing (Gates, 2020). How it is going to evolve will be an object of future analysis. To date, it does not seem that it will overwhelm the health system in the way initially forecasted, given all the measures already in place and the Africa epidemic context: youthful population and general low mortality rate for the virus and possibility of self-management for the virus. Moreover, there seems to be some degree of community resilience which could compensate for the weaker state of Africa's health infrastructure. Community resilience refers to ability of a community to respond and recover from disaster using available resources (Bosher \& Chmutina, 2017; Patel, Rogers, Amlôt \& Rubin, 2017). This resilience can also be attributed to past community/local knowledge that has seen many countries in the region survive pandemic like Ebola, Malaria, HIV/AIDS among others.

African state capacity to measure up seems to exist, going by how governments have responded in the continent. One could advocate that same urgency and response should be extended to other governance issues. 


\section{REFERENCES}

Adeoye, A., Allison, S., Atabong, A. B., \& Brima, A. S. (2020, April 27). 'Crisis, What crisis? How not to handle a pandemic'. Mail \& Gaurdian Continental edition.

Adepoju, P. (2020) 'Nigeria responds to COVID-19; first case detected in sub-Saharan Africa', Nature, March. Retrieved from https://www.nature.com/ articles/d41591-020-00004-2

Africa Centre for Disease Control. (2020). African Union rolls out Partnership to Accelerate COVID-19 Testing, Africa Centre for Disease Control. Retrieved from https://africacdc.org/news-item/africanunion-rolls-out-partnership-to-accelerate-covid19-testing/

Agrawal, R. (2020). 'A Coronavirus Mystery: Why Are There So Few Cases in South Asia?'. Foreign Policy. Retrieved from https://foreignpolicy. com/2020/04/30/coronavirus-mystery-why-so-fewcases-south-asia-india-pandemic-lockdown/

Al-Jazeera. (2020). Egypt confirms coronavirus case, the first in Africa, Al jazeera. Retrieved from https:// www.aljazeera.com/news/2020/02/egypt-confirmscoronavirus-case-africa-200214190840134.html

Alamisi, D. (2020). COVID-19: Noguchi's pool testing flawed - Bright Simons, Ghana Reports. Retrieved from https://www.theghanareport.com/covid-19noguchis-pool-testing-flawed-bright-simons/

Bosher, L., \& Chmutina, K. (2017). Disaster Risk Reduction for the Built Environment. Hoboken, NJ: WILEY-Blackwell.

Child, K. (2020, May 01). 'Lockdown eases (slightly), but up to $7 \mathrm{~m}$ may lose jobs'. Business Day. Retrieved from https://www.businesslive.co.za/fm/ features/2020-05-01-lockdown-eases-slightly-butup-to-7m-may-lose-jobs/

David, N., \& Mash, R. (2020). 'Community-based screening and testing for Coronavirus in Cape Town, South Africa : Short report'. Afican Journal of primary Health Care and Family Medicine, 12(1), 1-3. Retrieved from https://doi.org/10.4102/ phcfm. v12i1.2499

Department of Health. (2020). Progress on Covid-19: South Africa Public health Response. Retrieved from https://ipasa.co.za/progress-on-covid-19-southafrica-public-health-response/
Department of Health Republic of South Africa. (2020). Risk-adjusted strategy for economic activity. Retrieved from http://files.ifea.com/RiskMgt/ COVID19/SA-COVID-phased-economicrecovery.pdf

Friedman, S. (2020). South Africa is failing on COVID-19 because its leaders want to emulate the First World, The Conversation. Retrieved from https://theconversation.com/south-africa-is-failingon-covid-19-because-its-leaders-want-to-emulatethe-first-world-142732

Gates, B. (2020, April 23). 'Bill Gates on How to fight future pandemics'. Economist. Retrieved from https:// www.economist.com/by-invitation/2020/04/23/billgates-on-how-to-fight-future-pandemics

Gemperle, S. M. (2018). 'Comparing anti-corruption agencies: a new cross-national index', International Review of Public Administration, 23(3), 156-175. Retrieved from https://doi.org/10.1080/12294659. 2018.1518002

Govindarajanm, V., \& Bagla, G. (2020). As Covid-19 Disrupts Global Supply Chains, Will Companies Turn to India?. Havard Business Review. Retrieved from https://hbr.org/2020/05/as-covid-19-disruptsglobal-supply-chains-will-companies-turn-to-india

Horowitz, J. (2020, March 12). 'Italy's Health Care System Groans Under Coronavirus - a Warning to the World'. New York Times. Retrieved from https://www.nytimes.com/2020/03/12/world/ europe/12italy-coronavirus-health-care.html

John Hopskins University. (2020). Coronavirus Resource Centre, Coronavirus Resource Centre. Retrieved from https://coronavirus.jhu.edu/map. html

Karlson, N., Stern, C., \& Klein, D. (2020). The underpinnings of Sweden's permissive COVID regime, CEPR Policy Portal. Retrieved from https://voxeu. org/article/underpinnings-sweden-s-permissivecovid-regime

Kell, F. (2020). Tanzania Evades COVID-19 Lockdown, but Restrictions Persist, Chatham House. Retrieved from https://www.chathamhouse. org/expert/comment/tanzania-evades-covid-19lockdown-restrictions-persist

National Institute for Communicable Disease. (2020). Coronavirus disease 2019(COVID-19) caused 
by a Novel Coronavirus (SARS-CoV-2) Guidelines for case-finding, diagnosis, and public health response in South Africa. Retrieved from https://www.nicd.ac.za/ wp-content/uploads/2020/07/NICD_DoH-COVID19-Guidelines_Final_3-Jul-2020.pdf

Nkengasong, J. (2020). 'Let Africa into the market for COVID-19 diagnostics'. Nature, 580(7805), 565. Retrieved from https://www.nature.com/articles/ d41586-020-01265-0

Office of the Secretary to the Government of the Federation Nigeria. (2020). Implementation Guideline for Containment of Covid-19. Retrieved from https:// covidlawlab.org/wp-content/uploads/2020/06/ Implementation-Guidlines-for-Containmentunlock.pdf

Our World in Data. (2020). The positive rate: Are countries testing enough to monitor their outbreak? Our World in Data Covid Dashboard. Retrieved from https://ourworldindata.org/coronavirus-testing

Patel, S. S., Rogers, M. B., Amlôt, R., \& Rubin, G. J. (2017, February). 'What Do We Mean by "Community Resilience"? A Systematic Literature Review of How It Is Defined in the Literature'. PLOS Current Disaster. Retrieved from http://currents. plos.org/disasters/index.html\%3Fp=28783.html

Quah, D. (2020). 'Singapore's policy response to COVID-19'. In R. Baldwin, \& B. Weder-di-Mauro (Eds.), Mitigating the COVID Economic Crisis: Act Fast and Do Whatever it Takes (pp. 103-117). London, UK: Centre for Economic Policy Research Press. Retrieved from https://voxeu.org/content/ mitigating-covid-economic-crisis-act-fast-and-dowhatever-it-takes
Reuters. (2020a, March 22). 'Cuban doctors head to Italy to battle coronavirus'. Reuters. Retrieved from https://www.reuters.com/article/us-healthcoronavirus-cuba/cuban-doctors-head-to-italy-tobattle-coronavirus-idUSKBN219051

Reuters. (2020b). Virus exposes gaping holes in Africa's health systems. Reuters. Retrieved from https://graphics.reuters.com/HEALTHCORONAVIRUS/AFRICA/yzdpxoqbdvx/

Signé, L., \& Treacy, M. (2020). 'Covid-19 is accelerating multilateralism in Africa'. Washington Post. Retrieved from https://www.washingtonpost. com/politics/2020/07/27/covid-19-is-acceleratingmultilateralism-africa/\#click=https://t.co/ tZRSmoApT5

Sotola, O. D. (2020, April 14). 'Exiting Covid-19 Lockdown'. Punch Newspapers Nigeria. Retrieved from https://punchng.com/exiting-covid-19lockdown/.

State Department @TravelGov. (2020). Notice to Medical Worker seeking to work in the USA. Twitter. Retrieved from https://twitter.com/TravelGov/ status/1243335697202851843

Worldaware. (2020). COVID-19 Alert: African Countries Tightening Travel Restrictions as of April 2. WorldAware. Retrieved from https://www. worldaware.com/covid-19-alert-african-countriestightening-travel-restrictions-april-2

Worldometers Coronavirus. (2020). COVID-19 Coronavirus Pandemic. Worldometers Coronavirus. Retrieved from https://www.worldometers.info/ coronavirus/ 


\section{David Olusegun Sotola}

https://orcid.org/0000-0001-5813-7550

School of Public Leadership Stellenbosch University. E-mail: 21464936@sun.ac.za

\section{Pregala Pillay}

https://orcid.org/0000-0002-2101-962X

Professor School of Public Leadership Stellenbosch University South Africa. E-mail: pregala.pillay@sun.ac.za

\section{Hafte Gebresalassie}

https://orcid.org/0000-0002-3436-641X

School of Public Leadership Stellenbosch University. E-mail: hafte21hg@gmail.com 